\title{
A Practical Review of C-Peptide Testing in Diabetes
}

\author{
Emma Leighton · Christopher AR Sainsbury • Gregory C. Jones
}

Received: March 23, 2017 / Published online: May 8, 2017

(C) The Author(s) 2017. This article is an open access publication

\begin{abstract}
C-peptide is a widely used measure of pancreatic beta cell function. It is produced in equimolar amounts to endogenous insulin but is excreted at a more constant rate over a longer time. Methods of estimation include urinary and unstimulated and stimulated serum sampling. Modern assays detect levels of c-peptide which can be used to guide diabetes diagnosis and management. We explore the evidence behind the various tests available. We recommend the glucagon stimulation c-peptide testing owing to its balance of sensitivity and practicality. C-peptide levels are associated with diabetes type and duration of disease. Specifically a c-peptide level of less than $0.2 \mathrm{nmol} / \mathrm{l}$ is associated with a diagnosis of type 1 diabetes mellitus (T1DM). C-peptide level may correlate with microvascular and macrovascular complications and future use of insulin therapy, as well as likely response to other individual therapies. We explore the potential uses of c-peptide measurement in clinical practice.
\end{abstract}

Enhanced content To view enhanced content for this article go to http://www.medengine.com/Redeem/ 1E18F06019514A5F.

E. Leighton · C. A. Sainsbury · G. C. Jones ( $₫)$ Diabetes Department, Gartnavel General Hospital, Glasgow, UK

e-mail: g.jones3@nhs.net
Keywords: C-peptide; Diabetes; Insulin; Type 1 diabetes; Type 2 diabetes

\section{INTRODUCTION}

C-peptide is the part of proinsulin which is cleaved prior to co-secretion with insulin from pancreatic beta cells. Produced in equimolar amounts to endogenous insulin, it is not a product of therapeutically administered exogenous insulin and has been widely used as a measure of insulin secretion. This review of the literature will identify the main indications and rationale for c-peptide sampling in clinical practice and compare the available methods of c-peptide testing. Overall, the aim is to offer a rationale for the practical and pragmatic use of c-peptide testing to guide clinical management of individuals with diabetes.

This article is based on previously conducted studies and does not involve any new studies of human or animal subjects performed by any of the authors.

\section{WHAT IS C-PEPTIDE AND WHY MIGHT IT BE USEFUL IN CLINICAL PRACTICE?}

C-peptide is a useful and widely used method of assessing pancreatic beta cell function $[1,2]$. After cleavage of proinsulin, insulin and the 
31-amino-acid peptide c-peptide are produced in equal amounts [3, 4]. So why is c-peptide testing preferable to insulin as a guide to beta cell function? The degradation rate of c-peptide in the body is slower than that of insulin (half-life of 20-30 min, compared with the half-life of insulin of just 3-5 min), which affords a more stable test window of fluctuating beta cell response. In healthy individuals the plasma concentration of c-peptide in the fasting state is $0.3-0.6 \mathrm{nmol} / \mathrm{l}$, with a postprandial increase to $1-3 \mathrm{nmol} / \mathrm{l}$ [4]. Half of all insulin secreted by the pancreas is metabolized in the liver by first-pass metabolism, whereas c-peptide has negligible hepatic clearance. C-peptide is cleared in the peripheral circulation at a constant rate, whereas insulin is cleared variably making direct measurement less consistent. In insulin-treated patients with diabetes, measurement of c-peptide also avoids the pitfall of cross-reaction of assay between exogenous and endogenous insulin.

C-peptide is a cornerstone of the assessment of non-diabetes-associated hypoglycemia and the diagnosis of conditions such as insulinoma and factitious hypoglycemia but this area is beyond the scope of this article.

Increasing evidence suggests that c-peptide may also be useful in predicting future levels of glycemic control, response to hypoglycemic agents, and risk of future diabetes complications. We will examine the key methods of sample collection for c-peptide determination and advise on what is most reliable and practical. Furthermore, we will summarize the clinical relevancy of c-peptide sampling through review of the evolving literature on this subject.

\section{WHAT ARE THE POTENTIAL PROBLEMS WITH C-PEPTIDE MEASUREMENT?}

The majority of c-peptide is metabolized by the kidneys with $5-10 \%$ then excreted unchanged in the urine $[1,5]$. This can make c-peptide measurement in individuals with chronic kidney disease inaccurate.

Modern ultrasensitive c-peptide assays are able to detect c-peptide values as low as
$0.0015-0.0025 \mathrm{nmol} / 1$ [6]. It is also important to be aware that cross-reactivity with proinsulin must be less than $10 \%$, which is generally the case for modern assays [7]. The presence of large numbers of anti-insulin antibodies that bind both proinsulin and c-peptide can give a falsely high c-peptide reading. When considering c-peptide estimation it is important to be aware of which assay your local laboratory uses and in particular which method of collection they routinely process.

It should be noted that c-peptide will be expressed in nanomoles per liter in this article, as opposed to picomoles per milliliter, picomoles per liter, or nanograms per milliliter, which are often quoted in the literature $(1 \mathrm{nmol} /$ $\mathrm{l}=1 \mathrm{pmol} / \mathrm{ml}=1000 \mathrm{pmol} / \mathrm{l}=3 \mathrm{ng} / \mathrm{ml})$.

\section{METHODS OF COLLECTION OF C-PEPTIDE}

Various methods of c-peptide estimation have been advocated. These have been summarized in Table 1. Urinary c-peptide (UCP) is a non-invasive test, which can be performed in an outpatient setting [8]. When collected in boric acid UCP is stable at room temperature for up to 3 days. In patients with normal renal function, UCP quantity is reflective of $5-10 \%$ of total c-peptide secreted by the pancreas [9]. The $24 \mathrm{~h}$ urinary c-peptide sample collection ( $24 \mathrm{~h} \mathrm{UCP}$ ) is a more time-consuming method, which is inconvenient for the patient, making it a less attractive option than spot UCP. In subjects with normal glucose tolerance urinary c-peptide to creatinine ratio (UCPCR) has been shown to correlate well with $24 \mathrm{~h}$ urinary c-peptide [5]. This suggests that UCPCR might be a simple, reliable, and convenient method of estimating c-peptide. Gender differences may arise, however, owing to women having less muscle mass, resulting in reduced urine creatinine and higher UCPCR values than men [10]. In one study UCPCR was found to significantly correlate with fasting c-peptide in female subjects, with spot UCP being a better measure of beta cell function in male subjects [2].

Serum c-peptide has traditionally been thought to be an inconvenient method as 


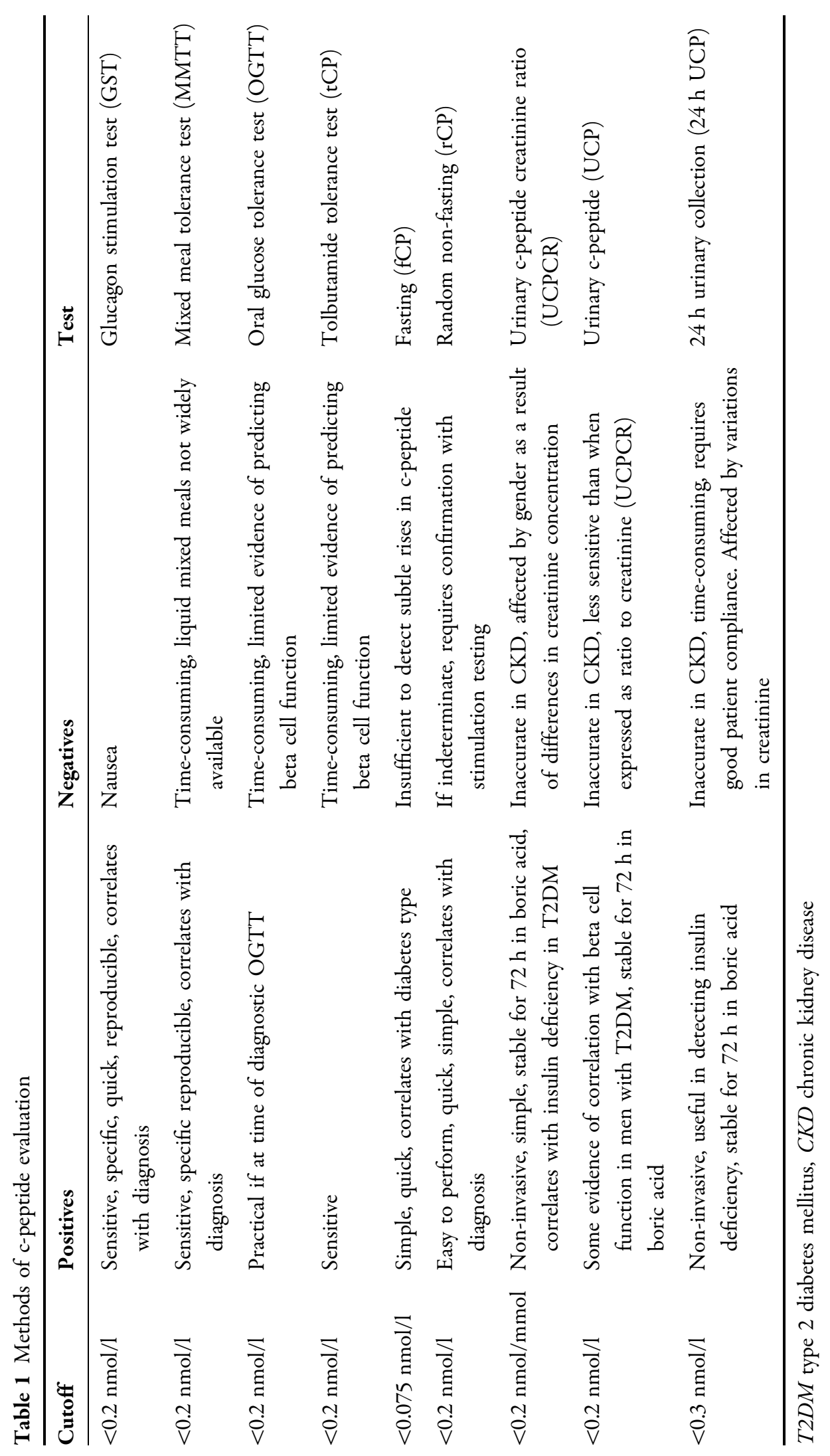


immediate lab analysis is required before degradation (when collected in serum gel or plain sample tubes). This is because c-peptide is a small linear peptide, which is susceptible to enzyme proteolytic cleavage [7]. Gel tubes are therefore traditionally required to be transported to the lab on ice, promptly centrifuged and separated, then stored in frozen conditions unless lab analysis is possible at that center. However, c-peptide sample collection for c-peptide determination in whole blood in EDTA prepared tubes is stable at room temperature for up to $24 \mathrm{~h}$ [11].

Venous blood c-peptide levels can be measured in the random, fasting, or stimulated state [12]. Random samples are taken at any time during the day without consideration of recent food intake, whereas fasting samples are taken after an 8- to 10-h fast. Stimulation methods include using glucagon, intravenous/oral glucose, tolbutamide, sulfonylurea, and glucose-like peptide 1 , amino acids, or a mixed meal [7, 13-15].

Random non-fasting sampling (rCP) is the simplest method allowing flexibility to test in an outpatient or inpatient setting. rCP has been shown to correlate with fasting c-peptide (fCP) and post glucagon stimulation test (GST) samples in subjects with well-defined type 1 or type 2 diabetes [16]. Similarly rCP has been shown to correlate with $90 \mathrm{~min}$ mixed meal tolerance test (MMTT) c-peptide responses $\quad(r=0.91$, $p<0.0001)$ [17].

Originally described in 1977 , the GST is the most widely used of the provocation methods and is described in Fig. 1 [18]. The MMTT has been advocated as the "gold standard" of stimulation testing owing to excellent sensitivity in detecting residual insulin secretion [7, 19, 20]. In the MMTT, a weight-based liquid meal, such as Sustacal or Boost, is ingested over $5 \mathrm{~min}$ and timed samples for c-peptide determination can be taken $10 \mathrm{~min}$ prior to ingestion $(t=-10)$, at baseline $(t=0)$, and at $15,30,60,90$, and 120 min. C-peptide can also be measured across a $75 \mathrm{~g}$ oral glucose tolerance test (OGTT) [21]. C-peptide sampling as part of the OGTT has been found to significantly correlate with insulin secretion in type 2 diabetes mellitus (T2DM), when samples are taken at 0, 30, 60, 90, and $120 \mathrm{~min}$ (with the possibility of extending this to include sampling at 150, 180, 240, and $300 \mathrm{~min}$ ) [22]. Adding c-peptide determination to the protocol of an OGTT may therefore be a practical means of estimating beta cell function when the test is already being performed for diagnostic reasons, if further interval sampling is taken between 0 and $120 \mathrm{~min}$.

Which method of c-peptide collection is most clinically useful? GST has been shown to be superior in sensitivity to use of glucose or tolbutamide as substrates, with a twofold higher mean increase in c-peptide response [13]. We summarize the method of performing the GST in Fig. 1. Further studies have demonstrated that c-peptide levels following GST are a consistently sensitive measure of beta cell function, which may be associated with diabetes type and future use of insulin $[9,19,23,24]$. In patients with diabetes who were both insulin and non-insulin treated, GST demonstrated a $29 \%$ rise in c-peptide compared to $19 \%$ rise postprandially [24]. Further support of the clinical utility of stimulated c-peptide comes from the American Diabetes Association (ADA), which sponsored a workshop evaluating the use of c-peptide in assessment of beta cell function. They concluded that MMTT and GST were recommended owing to their superior sensitivity and specificity [7].

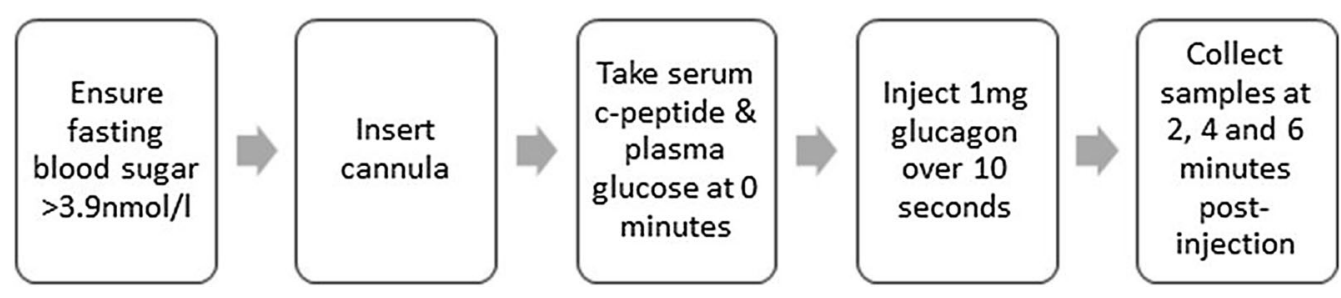

Fig. 1 Glucagon-stimulated c-peptide test (GST) 
MMTT and GST are known to be sensitive and reproducible tests of residual beta cell function in type 1 diabetes mellitus (T1DM), with peak responses seen at 90 and $6 \mathrm{~min}$, respectively [19]. Two parallel randomized trials by the TrialNet group and by the European C-peptide Trial (ECPT) found moderately superior rises in peak response with the MMTT [19]. Reproducibility and patient completion for both tests were high. Although a majority of patients experienced nausea with the GST, which reduced overall patient satisfaction, patients older than 13 years preferred the GST to the MMTT because of the shorter duration and ease of the test.

It is our view that serum c-peptide testing after stimulation is superior to $\mathrm{rCP}, \mathrm{fCP}$, and urinary testing. Despite the fact that fasting or random non-fasting c-peptide measurements are easier to perform, are less expensive, and can often be carried out in a clinic setting, their ability to detect subtle levels of c-peptide is significantly limited. This difference could be important in T2DM patients who may be unnecessarily started on insulin therapy despite having adequate beta cell reserve. Applying a cutoff value of less than $0.2 \mathrm{nmol} / 1$ to rCP testing has been shown to correlate well with stimulated c-peptide $(r=0.91)$ in insulin-treated subjects with diabetes, but levels of rCP out of this range require confirmation by another method [17]. Likewise urinary testing, whether collected as a UCPCR or $24 \mathrm{~h}$ collection, has been shown to be far less sensitive and is inaccurate in individuals with any degree of renal impairment. Whilst in a research setting the MMTT may potentially be preferable owing to its increased peak response, we feel that in day-to-day clinical practice a $120 \mathrm{~min}$ test is too time-consuming and cumbersome. The GST is preferable owing to the short duration of the test leading to less patient inconvenience, coupled with good sensitivity and reproducibility of results.

\section{DIAGNOSIS AND DIABETES CLASSIFICATION}

C-peptide has been shown to denote endogenous insulin production and correlates with
Table 2 Indications for c-peptide measurement

Diagnostic

To define T1DM

Criteria for acceptance for CSII

To determine whether T1DM or T2DM

Diagnostic test for MODY

Diagnostic test for LADA, in addition to antibody testing

Prognostic

Marker of duration of diabetes

Lower levels are associated with microvascular complication risk in T1DM

Associated with glycemic variability/HbA1C level

Lower levels are associated with greater hypoglycemia risk

Therapeutic response

Lower baseline levels associated with increased need for insulin

Lower baseline levels associated with shorter time to insulin treatment

Higher levels present in patients who respond to metformin and glibenclamide in combination

Higher levels associated with response to thiazolidinediones

Correlates with reduction in $\mathrm{HbA1C}$ following initiation of GLP-1 agonist therapy

CSII continuous subcutaneous insulin infusion, $M O D Y$ maturity-onset diabetes of the young, $L A D A$ latent autoimmune diabetes of adults

type of disease, duration of diabetes, as well as age of diagnosis. The various practical applications of c-peptide measurement are summarized in Table 2.

In insulin-treated individuals, fCP less than $0.2 \mathrm{nmol} / \mathrm{l}$ and GST of less than $0.32 \mathrm{nmol} / \mathrm{l}$ have been found to correlate significantly with T1DM, with greater sensitivity and specificity than urinary testing [9]. 
The diabetes control and complications trial (DCCT) was the landmark study which helped generate the targets we presently use for T1DM. Entry to the DCCT required individuals to have insulin-dependent diabetes mellitus of at least 5 years' duration with a baseline mixed meal stimulated c-peptide of less than $0.2 \mathrm{nmol} / \mathrm{l}$ [25]. Later in the study, entry criteria were extended to include those with a baseline mixed meal stimulated c-peptide of up to $0.5 \mathrm{nmol} / \mathrm{l}$. The study determined that intensive treatment with three or more insulin injections or continuous subcutaneous insulin infusion (CSII) therapy reduces the incidence of microvascular complications and the later follow-up of the cohort showed a reduction in adverse cardiovascular outcomes $[26,27]$. As the rationale for intensive control with insulin in T1DM is based on data from the DCCT, it is logical that stimulated c-peptide is used as a method of defining T1DM.

There is some evidence that c-peptide may have a role in the diagnosis of latent autoimmune diabetes of adults (LADA), which can be misdiagnosed as T2DM [28-30]. fCP is significantly lower in LADA compared with T2DM [30]. Whilst c-peptide sampling may therefore be an effective initial screening tool for LADA, anti-GAD or anti-IA2 antibody measurement should be considered to confirm diagnosis.

C-peptide concentration has been shown to decline over decades with duration of diabetes $[6,31-33]$. DCCT data obtained at screening to enter the study showed that diabetes duration was associated with c-peptide value; $48 \%$ of individuals with T1DM of up to 5 years' duration had a mixed meal stimulated c-peptide of at least $0.2 \mathrm{nmol} / 1$ (corresponding with preserved beta cell function), but only $8 \%$ of those with diabetes duration 5-15 years had a stimulated c-peptide of at least $0.2 \mathrm{nmol} / \mathrm{l}[7,25]$. Recent cross-sectional studies confirmed that c-peptide declines over time and is significantly related to age of onset $(p<0.0001)$ with a younger age of onset (less than 10 years) resulting in a far more rapid c-peptide decline [6]. A higher percentage of detectable c-peptide has been found in those with T1DM aged older than 18 years, compared to those younger than 18 years [34].
Maturity-onset diabetes of the young (MODY) is a rarer, genetic form of diabetes, which can be misdiagnosed as T1DM [35]. C-peptide has been proposed as a useful biomarker in the detection of MODY prior to genetic testing. In MODY, whilst there is reduction in beta cell function, some insulin secretion is retained compared to T1DM. UCPCR has been used as a tool to discriminate between two of the most common types of MODY: HNF1A and HNF4A heterozygous mutations, and long-duration T1DM [36]. UCPCR was found to be significantly lower in subjects with type 1 diabetes of greater than 5 years' duration, compared with subjects with HNF1A/4A MODY $(p<0.0001)$.

The "Diabetes Diagnostics" app has been created by the University of Exeter diabetes research team as a convenient resource for the diagnosis of MODY and other types of diabetes on the basis of clinical criteria according to national and international guidelines in addition to c-peptide interpretation $[37,38]$.

C-peptide is a useful tool in the classification of diabetes. It can help differentiate T1DM, T2DM, and MODY. C-peptide is associated with duration of disease as well as age of diagnosis. Whilst c-peptide is useful in classifying diabetes it must always be interpreted in clinical context of disease duration, comorbidities, and family history.

\section{PREDICTION OF NEED FOR INSULIN}

There is limited evidence in the literature about whether c-peptide can effectively predict whether patients require insulin [23, 39]. An early prospective cohort study determined that a peak GST c-peptide of less than $0.6 \mathrm{nmol} / 1$ was associated with later treatment with insulin [23]. Further to this a retrospective cohort study in a single diabetes outpatient center in Sweden found that a median fasting c-peptide concentration at diagnosis was lower in patients immediately treated with insulin $(0.24 \mathrm{nmol} / \mathrm{l}$, range 0.10-1.54) compared with those managed initially with diet with or without oral therapy (0.73 nmol/l, range 0.10-4.10) [39]. fCP of less 
than $0.25 \mathrm{nmol} / \mathrm{l}$ at diagnosis as an independent factor had $60 \%$ sensitivity and $96 \%$ specificity for association with insulin treatment at follow-up. Islet cell antibody (ICA) positivity in combination with low fCP was found to significantly correlate with future insulin treatment. All such cohort studies are subject to potential bias in that the c-peptide result may in itself influence the decision to start insulin.

Time to insulin treatment may also be associated with c-peptide response [40]. In a retrospective study of insulin-treated individuals with T2DM, time to insulin prescription in individuals with an MMTT c-peptide of at most $0.2 \mathrm{nmol} / \mathrm{l}$ (suggesting absolute insulin deficiency) was 2.5 (1.5-3) years compared to 6 (3-10.75) years for those with a mixed meal stimulated c-peptide of greater than $0.2 \mathrm{nmol} / \mathrm{l}$ $(p=0.005)$.

The ability of c-peptide estimation to confirm the appropriateness of intensive insulin treatment has been practically applied in some healthcare systems such as being used as a criterion for determining if an individual with diabetes is a suitable candidate for CSII therapy [41].

A stimulated c-peptide concentration of at most $0.2 \mathrm{nmol} / \mathrm{l}$ may be used as a cutoff value predictive of poor beta cell reserve and likely requirement of insulin therapy, for which intensive therapy has been shown to be efficacious. Additionally, a fasting c-peptide value less than $0.25 \mathrm{nmol} / \mathrm{l}$, alone or especially if in combination with ICA positivity, is a useful test for determining likely future insulin treatment.

\section{PREDICTION OF RESPONSE TO NON-INSULIN THERAPIES IN T2DM}

There is variable evidence to support the use of c-peptide to predict response to non-insulin treatments for T2DM.

Higher MMTT stimulated c-peptide has been shown to be present in patients who respond to metformin and glibenclamide in combination but GST c-peptide did not predict response to glibenclamide alone $[42,43]$. High fCP is associated with response to the thiazolidinediones, rosiglitazone and pioglitazone, which is in keeping with their action of reducing insulin resistance [44, 45]. Whilst cohort studies of mixed DPP4 inhibitor use has shown that initial higher fCP predicts reduction of $\mathrm{HbA1c}$, this association was not found in a retrospective study of sitagliptin use in addition to metformin or a sulfonylurea [46-48].

However, higher c-peptide levels do seem to predict response to GLP-1 agonists. Better insulin response to glucose is seen in those patients taking liraglutide with higher GST c-peptide levels [49]. The clinical relevance of this finding is confirmed by studies showing that fCP and post-meal UCPCR both predict reduction of $\mathrm{HbA1c}$ following initiation of treatment with an GLP-1 agonist [50, 51].

In patients taking SGLT-2 inhibitors, c-peptide may be able to identify those patients who are at risk of diabetic ketoacidosis. Unfortunately, low c-peptide is not a consistent finding in patients on SGLT-2 inhibitors who have ketoacidosis $[52,53]$.

\section{CAN C-PEPTIDE PREDICT DIABETES COMPLICATIONS?}

An area of growing research is the question as to whether c-peptide can be used to predict diabetes complications. This has been summarized in Table 2.

Lower c-peptide values have been associated with poorer glycemic control and hence increased HbA1c values [6, 54].

Retrospective analysis of subjects included for screening for the DCCT found a correlation between c-peptide and clinical outcomes in insulin-dependent diabetes $[26,55]$. Uniformly in the "intensive" treatment group higher and sustained levels of c-peptide (i.e., greater than $0.2 \mathrm{nmol} / \mathrm{l}$ consistently) were associated with reduced incidence of retinopathy and nephropathy $(p<0.05)$. The risk reduction of retinopathy between "non-responder" (c-peptide less than $0.2 \mathrm{nmol} / \mathrm{l}$ ) and "responder" (c-peptide $0.2-0.5 \mathrm{nmol} / \mathrm{l}$ ) groups was $58 \%$ (26-76\%, $p=0.0025)$, and for sustained retinopathy the risk reduction was even higher at $79 \%(9-95 \%, p=0.0360)$ [54]. For severe 
hypoglycemia the risk reduction between "non-responders" and "responders" was 45\% (38-52, $p<0.0001)$. In another cross-sectional analysis, c-peptide less than $0.01 \mathrm{nmol} / \mathrm{l}$ was found to correlate with increased incidence of nephropathy, neuropathy, retinopathy, and foot ulcers $(p=0.03$, odds ratio 3.1) [6].

Lower levels of c-peptide and decreased beta cell function have been linked to greater levels of glucose variability $[20,56]$. As glucose variability is known to be associated with increased complications and mortality in patients with diabetes it is possible that c-peptide may be a predictor of future outcomes independent of HbA1c levels [57-59].

Whilst c-peptide levels may be associated with complications in diabetes through a glycemic mechanism it may also have direct molecular effects. C-peptide is generally thought of as a biologically inert peptide of interest only as a surrogate marker for insulin levels but this may be overly simplistic. C-peptide has been shown in vitro to inhibit endothelial cell reactive oxygen species (ROS) formation in the presence of hyperglycemia $[60,61]$. C-peptide also downregulates the expression of several hyperglycemia-induced adhesion molecules, including vascular cellular adhesion molecule 1 (VCAM1), reducing leukocyte adhesion to endothelial cell walls and preventing the early stages of atherosclerosis plaque formation [4].

Some preliminary randomized controlled trials demonstrate that giving subcutaneous c-peptide alongside insulin to individuals with T1DM may ameliorate microvascular complications, such as albuminuria and autonomic nerve dysfunction [62, 63]. However these studies only included small cohort numbers and require further replication.

Higher levels of c-peptide have consistently been shown to be associated with cardiovascular and all-cause mortality in people without diabetes [64-66]. This is presumably because raised c-peptide levels are a marker of insulin resistance and metabolic syndrome phenotype. Similar findings have been observed in some, but not all, observational studies in T2DM [67-70].
It seems that c-peptide is associated with increasing microvascular complications when low and macrovascular complications when high, which may make interpretation of results difficult when attempting to predict outcomes in clinical practice.

\section{GUIDELINES}

Despite studies showing the potential importance of c-peptide as a marker in the diagnosis and of outcomes in diabetes, current national and international guidelines do not advocate its use $[71,72]$.

According to the American Diabetes Association (ADA) guidelines, the role of c-peptide in the diagnosis of diabetes is currently limited to unusual or ambiguous cases of T1 or T2DM [73]. C-peptide is still felt to be a more important tool in research rather than in day-to-day clinical practice. An ADA-sponsored workshop in 2001 concluded unanimously that c-peptide estimation be used as the most appropriate outcome measure for preservation of beta cell function [7]. In recent guidelines developed by the American Association of Clinical Endocrinologists (AACE) and American College of Endocrinology (ACE), documenting the levels of c-peptide is recommended when there is doubt over the diagnosis T1 or T2DM [74]. A recent systematic review supported the diagnostic utility of c-peptide, recommending its use as the principal baseline measure of insulin deficiency [75].

Given the evidence, we would anticipate that c-peptide estimation may in future have a more prominent role in guidelines relating to diagnosis and management of diabetes.

\section{POTENTIAL FUTURE USES}

Potential future uses of c-peptide are broad including aiding appropriate diagnosis, guiding therapy choices, and predicting morbidity in diabetes. Stimulated c-peptide sampling is a sensitive and specific test, which can help determine type and duration of diabetes. With many previous studies including small numbers 
and using fasting c-peptide, future work could include prospective design, larger patient populations, and use stimulated c-peptide as a more accurate parameter. Furthermore, evidence is currently limited with respect to predicting rarer forms of primary diabetes, such as MODY or LADA. In time, c-peptide may become a screening tool to reduce need for autoantibody tests being performed in certain patients to confirm or exclude a diagnosis. A lower c-peptide, specifically less than $0.2 \mathrm{nmol} / \mathrm{l}$, can most likely predict requirement for insulin, but can values be used to predict likely time until insulin prescription? Similarly, can c-peptide sampling be used to guide the safe discontinuation of therapy? Lower c-peptide values have been shown to correspond with increased incidence of microvascular complications. It would be interesting to determine whether c-peptide concentrations are associated with increased macrovascular morbidity and mortality.

\section{CONCLUSIONS}

C-peptide is a useful indicator of beta cell function, allowing discrimination between insulin-sufficient and insulin-deficient individuals with diabetes. Various methods of sampling are available, including a urinary c-peptide to creatinine ratio, fasting serum c-peptide, and stimulated c-peptide. Owing to sensitivity, reproducibility, and convenience of the test, we would recommend glucagon stimulation testing in clinical practice. C-peptide has been shown to correlate with diabetes type, duration of disease, and age of diagnosis. Interestingly c-peptide has been demonstrated to be associated with microvascular complications. This requires further study but preliminary evidence suggests that in future, alongside HbA1C, sampling for c-peptide may be used as an integral diagnostic and monitoring tool.

\section{ACKNOWLEDGEMENTS}

No funding or sponsorship was received for this study or publication of this article. The article processing charges were funded by the authors.
All named authors meet the International Committee of Medical Journal Editors (ICMJE) criteria for authorship for this manuscript, take responsibility for the integrity of the work as a whole, and have given final approval for the version to be published.

Compliance with Ethics Guidelines. This article is based on previously conducted studies and does not involve any new studies of human or animal subjects performed by any of the authors.

Disclosures. The authors of this article, Emma Leighton, Christopher AR Sainsbury, and Gregory C. Jones, have nothing to disclose.

Data Availability. Data sharing is not applicable to this article as no datasets were generated or analyzed during the current study.

Open Access. This article is distributed under the terms of the Creative Commons Attribution-NonCommercial 4.0 International License (http://creativecommons.org/licenses/ by-nc/4.0/), which permits any noncommercial use, distribution, and reproduction in any medium, provided you give appropriate credit to the original author(s) and the source, provide a link to the Creative Commons license, and indicate if changes were made.

\section{REFERENCES}

1. Jones AG, Hattersley AT. The clinical utility of C-peptide measurement in the care of patients with diabetes. Diabet Med. 2013;30:803-17.

2. Kulkarni CM, Patil S. Urinary C-peptide and urine C-peptide/creatinine ratio (UCPCR) are possible predictors of endogenous insulin secretion in T2DM subjects-a randomized study. Int J Pharma Bio Sci. 2016;7:443-446.

3. Steiner DF, Cunningham D, Spigelman L, Aten B. Insulin biosynthesis: evidence for a precursor. Science. 1967;157:697-700.

4. Yosten GLC, Maric-Bilkan C, Luppi P, Wahren J. Physiological effects and therapeutic potential of 
proinsulin C-peptide. Am J Physiol Endocrinol Metab. 2014;307:E955-68.

5. McDonald TJ, Knight BA, Shields BM, Bowman P, Salzmann MB, Hattersley AT. Stability and reproducibility of a single-sample urinary C-peptide/creatinine ratio and its correlation with 24-h urinary C-peptide. Clin Chem. 2009;55:2035-9.

6. Kuhtreiber WM, Washer SLL, Hsu E, et al. Low levels of C-peptide have clinical significance for established type 1 diabetes. Diabet Med. 2015;32:1346-53.

7. Palmer JP, Fleming GA, Greenbaum CJ, et al. C-peptide is the appropriate outcome measure for type 1 diabetes clinical trials to preserve beta-cell function: report of an ADA workshop, 21-22 October 2001. Diabetes. 2004;53:250-64.

8. Bowman P, McDonald TJ, Shields BM, Knight BA, Hattersley AT. Validation of a single-sample urinary C-peptide creatinine ratio as a reproducible alternative to serum C-peptide in patients with type 2 diabetes. Diabet Med. 2012;29:90-3.

9. Gjessing HJ, Matzen LE, Faber OK, Frøland A. Fasting plasma C-peptide, glucagon stimulated plasma $\mathrm{C}$-peptide, and urinary C-peptide in relation to clinical type of diabetes. Diabetologia. 1989;32:305-11.

10. Thomas NJ, Shields BM, Besser REJ, et al. The impact of gender on urine C-peptide creatinine ratio interpretation. Ann Clin Biochem. 2012;49:363-8.

11. McDonald TJ, Perry MH, Peake RWA, et al. EDTA improves stability of whole blood C-peptide and insulin to over 24 hours at room temperature. PLoS One. 2012;7:e42084.

12. Pozzan R, Dimetz T, Gazzola HM, Gomes MB. The C-peptide response to a standard mixed meal in a group of Brazilian type 1 diabetic patients. Braz J Med Biol Res. 1997;30:1169-74.

13. Mirel RD, Ginsberg-Fellner F, Horwitz DL, Rayfield EJ. C-Peptide reserve in insulin-dependent diabetes. Comparative responses to glucose, glucagon and tolbutamide. Diabetologia. 1980;19:183-8.

14. Ludvigsson J. Methodological aspects on C-peptide measurements. Acta Med Scand Suppl. 1983;671:53-9.

15. Greenbaum CJ, Harrison LC, Immunology of Diabetes Society. Guidelines for intervention trials in subjects with newly diagnosed type 1 diabetes. Diabetes. 2003;52:1059-65.

16. Berger B, Stenström GSG. Random C-peptide in the classification of diabetes. Scand J Clin Lab Invest. 2000;60:687-93.
17. Hope SV, Knight BA, Shields BM, Hattersley AT, McDonald TJ, Jones AG. Random non-fasting C-peptide: bringing robust assessment of endogenous insulin secretion to the clinic. Diabet Med. 2016;33:1554-8.

18. Faber OK, Binder C. C-peptide response to glucagon. A test for the residual beta-cell function in diabetes mellitus. Diabetes. 1977;26:605-10.

19. Greenbaum CJ, Mandrup-Poulsen T, McGee PF, et al. Mixed-meal tolerance test versus glucagon stimulation test for the assessment of beta-cell function in therapeutic trials in type 1 diabetes. Diabetes Care. 2008;31:1966-71.

20. Hope SV, Knight BA, Shields BM, et al. Low c-peptide is associated with high glycaemic variability and hypoglycaemia in insulin-treated patients with type 2 diabetes. Diabet Med. 2016;33:144.

21. Breda E, Cavaghan MK, Toffolo G, Polonsky KS, Cobelli C. Oral glucose tolerance test minimal model indexes of beta-cell function and insulin sensitivity. Diabetes. 2001;50:150-8.

22. Okuno Y, Komada H, Sakaguchi K, et al. Postprandial serum C-peptide to plasma glucose concentration ratio correlates with oral glucose tolerance testand glucose clamp-based disposition indexes. Metabolism. 2013;62:1470-6.

23. Madsbad S, Krarup T, McNair P, et al. Practical clinical value of the C-peptide response to glucagon stimulation in the choice of treatment in diabetes mellitus. Acta Med Scand. 1981;210:153-6.

24. Koskinen PJ, Viikari JS, Irjala KM. Glucagon-stimulated and postprandial plasma C-peptide values as measures of insulin secretory capacity. Diabetes Care. 1988;11:318-22.

25. The DCCT Research Group. Effects of age, duration and treatment of insulin-dependent diabetes mellitus on residual beta-cell function: observations during eligibility testing for the Diabetes Control and Complications Trial (DCCT). J Clin Endocrinol Metab. 1987;65:30-6.

26. Diabetes Control and Complications Trial Research Group, Nathan DM, Genuth S, et al. The effect of intensive treatment of diabetes on the development and progression of long-term complications in insulin-dependent diabetes mellitus. N Engl J Med. 1993;329:977-86.

27. Diabetes Control and Complications Trial (DCCT)/ Epidemiology of Diabetes Interventions and Complications (EDIC) Study Research Group. Intensive diabetes treatment and cardiovascular outcomes in type 1 diabetes: the DCCT/EDIC study 30-year follow-up. Diabetes Care. 2016;39:686-93. 
28. Bell DSH, Ovalle F. The role of C-peptide levels in screening for latent autoimmune diabetes in adults. Am J Ther. 2004;11:308-11.

29. Arikan E, Sabuncu T, Ozer EM, Hatemi H. The clinical characteristics of latent autoimmune diabetes in adults and its relation with chronic complications in metabolically poor controlled Turkish patients with type 2 diabetes mellitus. J Diabetes Complications. 2005;19:254-8.

30. Kumar S, Subhakumari KN. Role of anti-GAD, anti-IA2 antibodies and C-peptide in differentiating latent autoimmune diabetes in adults from type 2 diabetes mellitus. Int $\mathrm{J}$ Diabetes Dev Ctries. 2016;36:313-9.

31. Madsbad S, Faber OK, Binder C, McNair P, Christiansen C, Transbøl I. Prevalence of residual betacell function in insulin-dependent diabetics in relation to age at onset and duration of diabetes. Diabetes. 1978;27(Suppl 1):262-4.

32. Wang L, Lovejoy NF, Faustman DL. Persistence of prolonged C-peptide production in type 1 diabetes as measured with an ultrasensitive C-peptide assay. Diabetes Care. 2012;35:465-70.

33. Greenbaum CJ, Beam CA, Boulware D, et al. Fall in C-peptide during first 2 years from diagnosis: evidence of at least two distinct phases from composite type 1 diabetes TrialNet data. Diabetes. 2012;61: 2066-73.

34. Davis AK, DuBose SN, Haller MJ, et al. Prevalence of detectable C-peptide according to age at diagnosis and duration of type 1 diabetes. Diabetes Care. 2015;38:476-81.

35. Hattersley A, Bruining J, Shield J, Njolstad P, Donaghue K, International Society for Pediatric and Adolescent Diabetes. ISPAD clinical practice consensus guidelines 2006-2007. The diagnosis and management of monogenic diabetes in children. Pediatr Diabetes. 2006;7:352-60.

36. Besser REJ, Shepherd MH, McDonald TJ, et al. Urinary C-peptide creatinine ratio is a practical outpatient tool for identifying hepatocyte nuclear factor 1-\{alpha\}/hepatocyte nuclear factor 4-\{alpha\} maturity-onset diabetes of the young from long-duration type 1 diabetes. Diabetes Care. 2011;34:286-91.

37. Shields BM, McDonald TJ, Ellard S, Campbell MJ, Hyde C, Hattersley AT. The development and validation of a clinical prediction model to determine the probability of MODY in patients with young-onset diabetes. Diabetologia. 2012;55:1265-72.

38. Diabetes Genes. Providing information for patients and professionals on research and clinical care in genetic types of diabetes. http://www. diabetesgenes.org/. Accessed 19 Feb 2017.

39. Landin-Olsson M, Nilsson KO, Lernmark A, Sundkvist G. Islet cell antibodies and fasting C-peptide predict insulin requirement at diagnosis of diabetes mellitus. Diabetologia. 1990;33:561-8.

40. Hope SV, Jones AG, Goodchild E, et al. Urinary C-peptide creatinine ratio detects absolute insulin deficiency in type 2 diabetes. Diabet Med. 2013;30:1342-8.

41. Centers for Medicare \& Medicaid Services. Decision memo for insulin pump: C-peptide levels as a criterion for use (CAG-00092R). CMS. 2004. https:// www.cms.gov/medicare-coverage-database/details/ nca-decision-memo.aspx?NCAId=109\&. Accessed 27 Jan 2017.

42. Hermann LS, Scherstén B, Melander A. Antihyperglycaemic efficacy, response prediction and dose-response relations of treatment with metformin and sulphonylurea, alone and in primary combination. Diabet Med. 1994;11:953-60.

43. Trischitta V, Italia S, Raimondo M, et al. Efficacy of combined treatments in NIDDM patients with secondary failure to sulphonylureas. Is it predictable? J Endocrinol Invest. 1998;21:744-7.

44. Kim YM, Cha BS, Kim DJ, et al. Predictive clinical parameters for therapeutic efficacy of rosiglitazone in Korean type 2 diabetes mellitus. Diabetes Res Clin Pract. 2005;67:43-52.

45. Blüher M, Lübben $G$, Paschke R. Analysis of the relationship between the Pro12Ala variant in the PPAR-gamma2 gene and the response rate to therapy with pioglitazone in patients with type 2 diabetes. Diabetes Care. 2003;26:825-31.

46. Kim SA, Shim WH, Lee EH, et al. Predictive clinical parameters for the therapeutic efficacy of sitagliptin in Korean type 2 diabetes mellitus. Diabetes Metab. J. 2011;35:159-65.

47. Demir S, Temizkan S, Sargin M. C-peptide levels predict the effectiveness of dipeptidyl peptidase- 4 inhibitor therapy. J Diabetes Res. 2016;2016: 4509603.

48. Oh TJ, Jung HS, Bae JH, et al. Clinical characteristics of the responders to dipeptidyl peptidase- 4 inhibitors in Korean subjects with type 2 diabetes. J Korean Med Sci. 2013;28:881-7.

49. Takabe M, Matsuda T, Hirota Y, et al. C-peptide response to glucagon challenge is correlated with improvement of early insulin secretion by liraglutide treatment. Diabetes Res Clin Pract. 2012;98:e32-5. 
50. Jones AG, McDonald TJ, Shields BM, et al. Markers of $\beta$-cell failure predict poor glycemic response to GLP-1 receptor agonist therapy in type 2 diabetes. Diabetes Care. 2016;39:250-7.

51. Thong KY, McDonald TJ, Hattersley AT, et al. The association between postprandial urinary C-peptide creatinine ratio and the treatment response to liraglutide: a multi-centre observational study. Diabet Med. 2014;31:403-11.

52. Redford C. SGLT2 inhibitors and the risk of diabetic ketoacidosis. Pract Diabetes. 2015;32:263-4.

53. Handelsman Y, Henry RR, Bloomgarden ZT, et al. American Association of Clinical Endocrinologists and American College of Endocrinology position statement on the association of SGLT-2 inhibitors and diabetic ketoacidosis. Endocr Pract. 2016;22:753-62.

54. Lachin JM, McGee P, Palmer JP, DCCT/EDIC Research Group. Impact of C-peptide preservation on metabolic and clinical outcomes in the diabetes control and complications trial. Diabetes. 2014;63:739-48.

55. Steffes MW, Sibley S, Jackson M, Thomas W. Beta-cell function and the development of diabetes-related complications in the diabetes control and complications trial. Diabetes Care. 2003;26: 832-6.

56. Kramer CK, Choi H, Zinman B, Retnakaran R. Glycemic variability in patients with early type 2 diabetes: the impact of improvement in $\beta$-cell function. Diabetes Care. 2014;37:1116-23.

57. Kilpatrick ES, Rigby AS, Atkin SL. A1C variability and the risk of microvascular complications in type 1 diabetes: data from the diabetes control and complications trial. Diabetes Care. 2008;31:2198-202.

58. Tang X, Li S, Wang Y, et al. Glycemic variability evaluated by continuous glucose monitoring system is associated with the $10-\mathrm{y}$ cardiovascular risk of diabetic patients with well-controlled HbA1c. Clin Chim Acta. 2016. doi:10.1016/j.cca.2016.08. 004.

59. Timmons JG, Cunningham SG, Sainsbury CAR, Jones GC. Inpatient glycemic variability and long-term mortality in hospitalized patients with type 2 diabetes. J Diabetes Complications. 2016. doi:10.1016/j.jdiacomp.2016.06.013.

60. Cifarelli V, Geng X, Styche A, Lakomy R, Trucco M, Luppi P. C-peptide reduces high-glucose-induced apoptosis of endothelial cells and decreases $\mathrm{NAD}(\mathrm{P}) \mathrm{H}$-oxidase reactive oxygen species generation in human aortic endothelial cells. Diabetologia. 2011;54:2702-12.
61. Bhatt MP, Lim Y-C, Hwang J, Na S, Kim Y-M, Ha K-S. C-peptide prevents hyperglycemia-induced endothelial apoptosis through inhibition of reactive oxygen species-mediated transglutaminase 2 activation. Diabetes. 2013;62:243-53.

62. Johansson BL, Borg K, Fernqvist-Forbes E, Kernell A, Odergren T, Wahren J. Beneficial effects of C-peptide on incipient nephropathy and neuropathy in patients with type 1 diabetes mellitus. Diabet Med. 2000;17:181-9.

63. Ekberg K, Brismar T, Johansson B-L, Jonsson B, Lindström P, Wahren J. Amelioration of sensory nerve dysfunction by C-peptide in patients with type 1 diabetes. Diabetes. 2003;52:536-41.

64. Min J-Y, Min K-B. Serum C-peptide levels and risk of death among adults without diabetes mellitus. CMAJ. 2013;185:E402-8.

65. de León AC, García JGO, Rodríguez IM, et al. C-peptide as a risk factor of coronary artery disease in the general population. Diab Vasc Dis Res. 2015;12:199-207.

66. Patel N, Taveira TH, Choudhary G, Whitlatch H, $\mathrm{Wu}$ W-C. Fasting serum C-peptide levels predict cardiovascular and overall death in nondiabetic adults. J Am Heart Assoc. 2012;1:e003152.

67. Hirai FE, Moss SE, Klein BEK, Klein R. Relationship of glycemic control, exogenous insulin, and C-peptide levels to ischemic heart disease mortality over a 16-year period in people with older-onset diabetes: the Wisconsin Epidemiologic Study of Diabetic Retinopathy (WESDR). Diabetes Care. 2008;31:493-7.

68. Pikkemaat M, Melander O, Mölstad S, Garberg G, Boström KB. C-peptide concentration, mortality and vascular complications in people with type 2 diabetes. The Skaraborg Diabetes Register. Diabet Med. 2015;32:85-9.

69. Bo S, Gentile L, Castiglione A, et al. C-peptide and the risk for incident complications and mortality in type 2 diabetic patients: a retrospective cohort study after a 14-year follow-up. Eur J Endocrinol. 2012;167:173-80.

70. Marx N, Silbernagel G, Brandenburg V, et al. C-peptide levels are associated with mortality and cardiovascular mortality in patients undergoing angiography: the LURIC study. Diabetes Care. 2013;36:708-14.

71. NICE. Diabetes in adults. List of quality statements. Guidance and guidelines. NICE. 2016. https://www. nice.org.uk/guidance/qs6/chapter/List-of-qualitystatements. Accessed 10 Feb 2017. 
72. WHO. Definition and diagnosis of diabetes mellitus and intermediate hyperglycaemia. World Health Organization. 2013. http://www.who.int/diabetes/ publications/diagnosis_diabetes2006/en/. Accessed 10 Feb 2017.

73. Sacks DB, Arnold M, Bakris GL, et al. Position statement executive summary: guidelines and recommendations for laboratory analysis in the diagnosis and management of diabetes mellitus. Diabetes Care. 2011;34:1419-23.
74. Handelsman Y, Bloomgarden ZT, Grunberger G, et al. American Association of Clinical Endocrinologists and American College of Endocrinology - clinical practice guidelines for developing a diabetes mellitus comprehensive care plan - 2015. https://www.aace.com/files/ dm-guidelines-ccp.pdf. Accessed 10 Feb 2017.

75. Shields BM, Peters JL, Cooper C, et al. Can clinical features be used to differentiate type 1 from type 2 diabetes? A systematic review of the literature. BMJ Open. 2015;5:e009088. 